Lysias 25 and the Intractable Democratic Abuses

Author(s): T. M. Murphy

Source: The American Journal of Philology, Vol. 113, No. 4 (Winter, 1992), pp. 543-558

Published by: The Johns Hopkins University Press

Stable URL: http://www.jstor.org/stable/295539

Accessed: 09-06-2015 19:04 UTC

Your use of the JSTOR archive indicates your acceptance of the Terms \& Conditions of Use, available at http://www.jstor.org/page/ info/about/policies/terms.jsp

JSTOR is a not-for-profit service that helps scholars, researchers, and students discover, use, and build upon a wide range of content in a trusted digital archive. We use information technology and tools to increase productivity and facilitate new forms of scholarship. For more information about JSTOR, please contact support@jstor.org. 


\section{LYSIAS 25 AND THE INTRACTABLE DEMOCRATIC ABUSES}

Nineteenth-and twentieth-century commentators of Lysias have more widely disagreed on the persona sustained by an anonymous member of the City faction 1 in Or. 25, "Defense against a Charge of Subverting the Democracy," than on that given any other "speaker" in the Lysianic corpus. ${ }^{2} \mathrm{~K}$. J. Dover found in this figure (whom I will call $\mathrm{X})$ a "distinctive" individual characterization ${ }^{3}$ but questioned whether Or. 25 could have been intended for delivery before a democratic court: "In this case the grounds for suspicion are the high level of generalisation maintained throughout the speech, the intellectual aloofness of the argument in 8-11, and the assurance of the inimical tone adopted in 25 towards certain individuals prominent in the closing years of the war." 4 However, though the likely date of composition can be set within narrow limits, Dover makes no effort to evoke the conditions which would have made delivery impossible or unlikely in spite of the fact that Athenian courts historically entertained issues more controversial than any raised in this speech. ${ }^{5}$ I hope to show the point of the "aloofness" and

'For a recent discussion of such key political terms as 'faction,' 'group,' 'tendency,' and 'party' and of their uses to describe the shifting, combative alignments of fifth- and fourth-century B.C. Athenian political life, see Barry Strauss, Athens after the Peloponnesian War: Class, Faction, and Policy 403-386 B.C. (London and Sydney 1986) 11-36. I am persuaded by Strauss's argument for 'faction' (27-28) as the best term in that it gives due emphasis to the importance of the individual leader without excluding considerations of policy, class, and economic interest.

${ }^{2}$ F. Blass, Die Attische Beredsamkeit ${ }^{2}$ I (Leipzig 1887) 515; P. Dobree, Adversaria I (Berlin 1831) 247; R. Rauchenstein, Ausgewählte Reden des Lysias I (Berlin 1848; rpr. Berlin 1963) 64; R. Jebb, The Attic Orators I (London 1876) 254; W. DeVries, A Rhetorical Study of the Types of Character in the Orations of Lysias (Baltimore 1892) 28; C. Adams, Lysias: Selected Speeches (London 1905; rpr. Norman, Okla. 1976) 260; P. Cloché, La restauration démocratique à Athènes en 403 avant J.-C. (Paris 1915) 387-94; I. Bruns, Das literarische Porträt der Griechen im fünften und vierten Jahrhundert vor Christi Geburt (Berlin 1896; rpr. Hildesheim 1961) 451.

${ }^{3}$ K. J. Dover, Lysias and the Corpus Lysiacum (Berkeley 1968) 78: "Personally I find the speaker of XXV the most distinctive, but he has not seemed so to others . . who have studied èthos in the orators." Cf. S. Usher, "Individual Characterisation in Lysias," Eranos 63 (1965) 119, n. 136.

${ }^{4}$ Dover (note 3 above) 188 . See note 11 below.

${ }^{5}$ According to Lys. 34 (preserved D. H. Lys. 31-33), a proposal of Phormisius to restrict the franchise to property owners was introduced shortly after the restoration: in 
argue that Dover has not recognized the role of generalization in the speech.

Dover's view exemplifies a serious deficiency in previous studies, their failure to relate Or. 25's rhetorical strategy to political conditions at the time of composition. The result has been the ascription by scholars of now this, now that individual or "dramatic" character to X where none is to be found. ${ }^{6}$ The speech, I argue, is a deliberation on Athenian public policy. Although it addresses the case of an individual, $\mathrm{X}$ offers a defense which covers in effect the entire City faction, rather than himself alone, and which proclaims a policy of expediency not just for himself but for his long-suffering faction as well. He therefore needs and is given only a generalized political persona. The result is a forensic speech whose content is properly deliberative in the technical sense. ${ }^{7}$

In undertaking this analysis my aim has not been, in the first instance, to uncover the "true" political motivation of the anonymous "speaker" or to determine his guilt or innocence of the charges against him. I have primarily tried to examine his social and political "image," as projected in the speech written for him, on the assumption that this image was intended by its author to appeal to the political awareness of its audience.

$\mathrm{X}$ invites the court to consider the past decade of catastrophic stasis in Athens as the work of an organized system of malfeasance and corruption, namely, the radical democracy; under it the relations of haves and have-nots have grown increasingly strained, with profit only to the sykophantai $(24,32,34)$. Comparison of the speech with Ps.Xenophon's Athenaiōn Politeia and the speech of Diodotus in Thucydides exposes X's political posture as that of a disaffected aristocrat conventionally claiming intellectual ascendancy over the democratic rank and file and moral ascendancy over current leaders of the restored de-

this a life-or-death issue was at stake for radical democracy. Whether Lys. 34 was delivered or not, the proposal itself is unlikely to have been fabricated by the speechwriter; see C. Hignett, A History of the Athenian Constitution to the End of the Fifth Century B.C. (Oxford 1952; rpr. 1970) 296-97; Cloché (note 2 above) 420.

${ }^{6} \mathrm{By}$ 'individual characterization' I mean those qualities of literary portrayal which seemingly discover to us a distinct individual rather than a type. To discuss individual characterization in this sense, Dionysius (Lys. 7, 9, respectively) uses the terms enargeia ('vividness') and prepon ('propriety'); see C. Carey, Lysias: Selected Speeches (Cambridge 1989) 10 , n. 49.

${ }^{7}$ That is, concerned with the expedient, bearing on the future, hortatory; cf. Arist. Rh. 1.3.3-6. 
mocracy. Contemporary evidence bearing on the gradual nature of the restoration to full radical democracy and, in particular, on the balance of factions in the impoverished Athenian state is scarce and of uneven reliability. It is my hope to have this rather neglected speech of Lysias' included among documents expressing the viewpoint of those who shied from both extremes, oligarchic and democratic, but especially from the latter in the obscure period between the restoration of democracy and the outbreak of the Corinthian War.

\section{OCCASION AND DATE}

The title of Or. 25, as preserved in the manuscripts, $\triangle \mathrm{HMOY}$ KАТА $\Lambda$ Y $\Sigma \Omega \Omega$ АПО $\Lambda$ ОГIA, "Defense on a Charge of Subverting the Democracy," is legally incorrect. I hope to show that the misnomer derives from the legitimate insight of an ancient compiler into what the speech really says about Athenian democracy. It supposes for audience, as the opening address to the jury indicates, an ordinary heliastic court of the restored democracy. Presumably (but not explicitly) the occasion for $\mathrm{X}$ is that of the preliminary scrutiny (dokimasia) required of all citizens entering public office $(10,23) .{ }^{8}$ No office is specified. The procedures for a scrutiny did not require candidates to offer proof of technical competence for office, but the examiners might find against anyone whose support for the laws and democratic constitution of Athens they had reason to doubt. ${ }^{9}$ (Though the testimony of Aristotle and Plato suggests that City men might have confidence in the amnesty, several passages in the Orators confirm that such charges were often heard after 403. $)^{10}$ The speech assumes that opponents have used the

${ }^{8}$ For the requirement see Arist. Ath. 55.2; Aeschin. 3.15; Lys. 15.2. For the occasion see Blass (note 2 above) 511; Jebb (note 2 above) 250-51; L. Gernet and M. Bizos, Lysias: Discours II (Paris 1955) 111; RE 5 (1905) 1270 s.v. dokimasia; Rauchenstein (note 2 above) 61-62.

${ }^{9}$ Arist. Ath. 55.3-4. Cf. the case of Theramenes (Lys. 13.10) and of Mantitheus (Lys. 16.3-8, 18), who claims to have provoked antipathy by wearing his hair in the aristocratic style.

${ }^{10}$ For the effectiveness of the amnesty see Arist. Ath. 40.2 and Plato Ep. 7.325b. But see also Lys. 26.9, 31.26. In Isoc. 18 an oligarch is defendant in a suit brought by a democrat at a time when the amnesty is of recent date (36). Further, Lys. 26.9 and Arist. 55.4 in correlation show how democrats might use the scrutiny process to weed out suspected oligarchs without the necessity of a formal charge against them. The law required the dikasts to vote on a prospective magistrate even if no one had any public 
occasion to accuse $X$ of supporting the activities of the Thirty, and on that basis to deny his fitness for office; but a lack of evidence supposedly hampers their case as X claims (5) they have proved him guilty of no crime and mentions no specific accusation. We can derive the political affiliation of his accusers only in broad terms; some at least are leaders of the restored democracy (11). X belittles them collectively as sykophantai $(3,24-25,27,29)$ - venal, power-hungry, and self-important $(3,30-31,34) .{ }^{11} \mathrm{He}$ is careful to distinguish them from the most influential and illustrious leaders of the Piraeus faction (28).

On the date of the speech, it is possible to be fairly definite. The bitter events associated with the rule of the Thirty Tyrants are still fresh enough in democratic memory for the men of the City to be resented (1, $5,24,30,35$ ); but the democracy has been restored long enough for there to be talk of Athens' going to war-against what group or state is not specified (30). The "speaker" claims that certain members of the Piraeus faction are fostering an aggressive or bellicose foreign policy that has caused the city to be "distrusted by the rest of the Greeks" (30), and this is most likely a reference to the democracy's violation of the accords in the Eleusis affair (9). Since this took place during the archonship of Xenainetus (Arist. Ath. 40.4), and if the occasion was indeed a scrutiny, Or. 25 was probably composed not sooner than May or June (the normal end-of-year time for the scrutiny of incoming officials $)^{12}$ in 400 B.C.

questions. In this way oligarchs might be denied office; technically, the amnesty would not be violated. X may plausibly have been the object of opportunistic charges that rested on little more than guilt by association (2). For a recent treatment of the amnesty see Martin Ostwald, From Popular Sovereignty to the Sovereignty of Law: Law, Society and Politics in Fifth-Century Athens (Berkeley 1986) 500.

"It is possible but not certain that the Epigenes, Demophanes, and Cleisthenes mentioned in sect. 25 figure as X's accusers on the present occasion. X cites them for sykophantia after the fall of the Four Hundred. Without patronymic or demotic, identifications are elusive. The Cleisthenes accused of being a career sykophantess may be the effeminate Cleisthenes ridiculed by Aristophanes at Ach. 118, Eq. 1374, Nu. 355, V. 1187, Av. 831, Th. 235 and 929, Lys. 1092, Ra. 48, 57, 422. See J. Kirchner, Prosopographia Attica (Berlin 1901-3) 8525. There is a slight possibility that Epigenes (Kirchner 4778) is the individual satirized by Aristophanes at Ec. 167; but the University of Toronto's Athenian Project directory lists about two hundred individuals of that name. (I am indebted to John Traill for this biographical datum.) Of Demophanes (Kirchner 3651) nothing can be conjectured; his is not an especially common name.

${ }^{12} \mathrm{On}$ the approximate date of composition I follow the view of (note 2 above) Blass I 512; Rauchenstein 62; and Cloché 389. 


\section{THE POLITICAL AFFILIATION OF $X$}

Let us consider first what $\mathrm{X}$ has to say about his background, past actions, and political affiliation during the decade of Athenian history under discussion.

The period 411-404. He was, he claims, without ambition to be in public life; he suffered no misfortune or disability at the hands of the radical democracy that would make him desire a change of constitution (12). He denies having been one of the Four Hundred in 411 (14). He claims to have fought in four sea battles (12). He five times fitted out a warship and contributed to many capital levies. He was very wealthy and met all his other public expenses with munificence (4, 11-13, 17; cf. Antipho. II Tetr. A.3.8). The foregoing brief claims on the court's goodwill are important because (1) they are all he will say about his activities then, and (2) they serve to excuse some sharp criticism of radical democracy.

The period 404/403. In the parts of the speech devoted to this crucial phase of X's past, he three times urges the jury to judge each person on the basis of his actions $(4-6,13,15)$. He admits remaining in the asty $(2-3,13-14)$; from this dikasts would infer that he was probably a member of the privileged Three Thousand who retained their citizenship under the oligarchy. He does not deny it. Nor does he deny that he was also, at least initially, a supporter of the oligarchy in $404 / 403 .{ }^{13} \mathrm{Had}$ he aided the democrats during the civil war, it would have been a most valuable point in his favor. In fact, he says, because of the tight control exercised by the Thirty, it was impossible for him to help anyone (16). Although he seems to say that loyalties shift as an inevitable consequence of stasis (9), he claims to have been politically inactive through the civil war, concerned with preserving his fortune in a time of violent upheaval (18).

$X$ has nothing to say about his actions in $404 / 403$, being content to affirm what he did not do. ${ }^{14} \mathrm{He}$ did not (he claims) serve on the Boule or

\footnotetext{
${ }^{13}$ See (note 2 above) Jebb 253; Cloché 393; and F. Ferckel, Lysias und Athen: Des Redners politische Stellung zum Gaststaat (Würzburg 1937) 95. By 'oligarch,' for the period 404/403, I mean any Athenian holding an archē under the Thirty Tyrants, all members of the oligarchic Boule, all citizens listed on the catalogue of Three Thousand by the Thirty. In other words, I use definite grades of time to construct a definition not based on nonquantifiable criteria such as opposition to this or that armed conflict or to socalled extreme democracy.

${ }^{14}$ Lys. 25.15-16. Cf. the case of the anonymous defendant in Isoc. 18.16.
} 
accept any other position of responsibility in the government. He inscribed no citizen's name on the Thirty's blacklist. He received no confiscated property. In short, he denies having harmed anyone during the oligarchy - but in a way that tells the jury nothing concrete about his activities during the period between the installation of the Thirty and the reconciliation of the Piraeus and City factions. (It could be difficult to assess responsibility for misdeeds committed under the Thirty, as $\mathrm{X}$ explicitly says at 13 and implicitly demonstrates at 14.) His "good con-

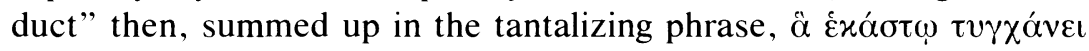
$\pi \varepsilon \pi \varrho \alpha \gamma \mu \varepsilon \dot{v} \alpha$, is avoidance of criminal activity, while he reckons his losses under the Thirty in terms of the prestige that would have been his to savor in a viable democracy (13).

$\mathrm{X}$ admits that he stayed in Athens to preserve his possessions (13, 18). As Jebb noticed, "he even implies a contrast between himself and those who had been true to the democracy at its need." 15 On the one hand, X claims that he was never disloyal to the democratic government while it existed (7). On the other, he aligns himself with the City faction in demanding his civic rights under the amnesty (3). He abhors the indiscriminate antidemocratic terror practiced by the Thirty. There are obviously people in Athens for whom he makes a tempting political target (18); but he knows the power of the City faction $(32,34-35)$ and is not afraid to warn the democracy: Threaten our position and no one will survive the next round of fighting! (Section 18 shows clearly the side he would take; cf. 6.)

His reticence makes it impossible to fix precisely within the ranks of the City faction in 404/403 the political affiliation of this individual, whom P. Cloché described as l'une des figures les plus curieuses et les plus complexes de l'époque. Was X in sympathy with one or more of the prominent oligarchs? Since $X$ did not find it necessary to flee to Eleusis after Munychia with the supporters of the Critias/Charicles faction, he probably was not one of their number. He claims to have spent large sums and to have fought bravely for Athens in the war with Sparta. He espouses a principled respect for the law (3) and harshly blames the radical democracy of $410 / 409$ for alleged judicial abuses (26). He can hardly have condemned the Thirty's dispatch of the most notorious sykophantai from the former democracy (see Xen. $H G$ 2.3.12); on the other hand, he was not for persecuting the democratic majority (19).

${ }^{15}$ Jebb (note 2 above) I 253. 
This posture and these views arguably associate $X$ with that substantial number of wealthy citizens who in 404 could find no better hope for themselves and Athens in her desperate hour than the controversial rhètōr Theramenes. ${ }^{16}$ We gauge the breadth of Theramenes' appeal from the datum provided by Aristotle (Ath. 34.3) that Archinus, Anytus, Cleitophon, Phormisius, and many others who later served the restored democracy were associated with him during the period of constitutional debate immediately preceding the installation of the Thirty. (It is important to recall that the Thirty were created to serve as a temporary framing committee for a new constitution, not as a permanent administration.) ${ }^{17}$ In Xenophon's account Theramenes aimed at a franchise open to all kaloikagathoi furnishing the traditional agatha of a hoplite or cavalryman. ${ }^{18}$ Even if a citizen had actually found favor with the people under the radical democracy (as Anytus or Thrasybulus had), it was unnecessary to exile him (Xen. $H G$ 2.3.42). This was oligarchy, but of a more inclusive kind than that demanded by Critias and his faction (Arist. Ath. 36.1).

Theramenes could present himself as one who avoided extremes. In 411 he persuaded the Athenian assembly to renounce its sovereignty (Lys. 12.65; Th. 8.68.4) but soon turned against the oligarchic regime of the Four Hundred (Th. 8.89.2, 94.1; Lys. 12.66-67). In 406 he served as a trierarch in the naval battle of Arginusae (Xen. $H G$ 1.7.5). He was elected strategos for $405 / 404$ but failed the preliminary scrutiny for that office, a piece of evidence that well illustrates the Athenians' ambivalence about him (cf. Lys. 13.10; Aristoph. Ran. 534-41). Theramenes' prominence in the government of the Thirty, the fact that he had personally selected ten of its members, was meant to reassure those citizens who belonged to neither political extreme. ${ }^{19}$

It was a reasonable expectation that Theramenes and others used to working within the written and unwritten laws of Athenian public life would continue to do so, and at first the new oligarchic regime avoided taking a high hand with the upper classes (Arist. Ath. 35.2; Diod. 14.4.12). But when Theramenes himself fell victim to the Thirty's reign of terror, ${ }^{20}$ those who had supported him, men with the profile of X, found

${ }^{16}$ See J. K. Davies, Athenian Propertied Families: 600-300 в.C. (Oxford 1971) no. 7234; J. Kirchner, Prosopographia Attica (Berlin 1901-3).

${ }^{17}$ Xen. $H G$ 2.3.2, 11; Arist. Ath. 35.1-2; Diod. 14.4.1-2.

${ }^{18}$ Xen. $H G$ 2.3.19, 39-40, 47-49. Cf. Lys. 25.4; Plato Rep. 495d-e, 556d, 590c-d. ${ }^{19}$ Lys. 12.76; Xen. $H G$ 2.3.17-18; cf. Diod. 14.4.1 on Theramenes' prestige.

${ }^{20}$ Xen. $H G$ 2.3.55; Arist. Ath. 37.1; Diod. 14.4.5-5.4. 
themselves caught between the murderous Critias faction then holding the asty and the men of Piraeus besieging it (Arist. Ath. 37.2). X is at pains to stress that during the disturbances he and others like him had no leadership with whom they could voluntarily identify, and therefore little organized factional influence on the terrible course of events (1516). ${ }^{21}$

Still, since $\mathrm{X}$ chooses to bring under review what he regards as the main points of his civic life (as would be expected if he were a citizen facing scrutiny [Lys. 16.9]), and since $X$ says that self-interest alone determines whether one gives political allegiance to oligarchy or democracy (8), we may feel invited to assess him as an individual case, as if his own story exemplified the principle at work. But the expectation of biographical data is scarcely met; this speech lacks a narrative section answering to the curiosity of democrats about his personal conduct. ${ }^{22}$

\section{THE DELIBERATIVE CHARACTER OF THE SPEECH}

Instead of individualized ethos we receive a commanding generalization on factional politics. Many commentators have noted in one way or another the icy thoroughness with which $\mathrm{X}$ derives all political and constitutional loyalties from self-interest (8):

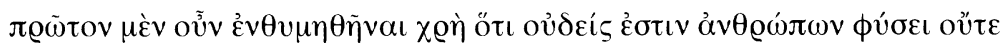

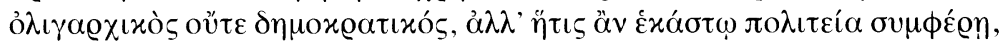

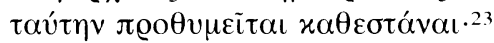

${ }^{21} \mathrm{X}$ does not mention Theramenes, possibly as a matter of prudence. It would not do for him to be too closely tied to any member of the Thirty, even a "moderate" leader like Theramenes. (On the authority of Lysias 12.62, one of the Thirty, Eratosthenes, facing the statutory audit of his office under the restored democracy, meant to invoke the name of Theramenes in his defense.) Indeed, Lysias had a strong personal motive not to invoke the name of Theramenes on his client's behalf. Or. 12 paints Theramenes as the mastermind behind both oligarchic revolutions and, to that extent, as a culprit in the murder of Lysias' brother Polemarchus. See Lys. 12.62-78; cf. 13.9, 17.

${ }^{22}$ Mantitheus in Or. 16 is also unforthcoming about his activities in $404 / 403$. Cf. Lys. 26.3.

23 " 'Democrats' are simply men who thought that all Athenian citizens should have a more or less equal say in the conduct of public affairs": D. M. Macdowell, Andokides: On the Mysteries (Oxford 1962; rpr. 1989) 190. 
The generalization is immediately paraphrased to underscore its importance (10):

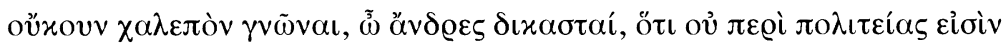

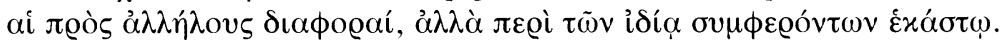

This does not leave him open to the charge of mere opportunism: when the men of the City were at war with the men of Piraeus, this wealthy citizen accepted the risks of the time and took his stand with the City faction. ${ }^{24}$ Given the near-omission of biographical detail ( Bíov), given the boast of good conduct under both democracy andimpossible to substantiate-the late oligarchy $(14,16-17)$, and given that much more rhetorical energy is spent on the damage that X's accusers are doing to Athens than on what they are doing to him, it is my thesis that $\mathrm{X}$ means for the generalization to be taken in a specific factional context, the material wealth and power of the amnestied City faction. ${ }^{25}$ For example, he says that his accusers know perfectly well who were the wrongdoers and who were the law-abiding citizens during the terror of 404/403 (1): here X has in mind the Spartan-imposed amnesty which specifically exempted from prosecution all but the oligarchic leadership (28). ${ }^{26}$ Further, the present hearing, whether it is a scru-

${ }^{24}$ Cloché (note 2 above) 393. Cf. the defendant in Lys. 31, who is said to have retired over the border to Oropus during the civil war, crossing back occasionally to rob elderly folk in the countryside (13-19). This is the sort of imputation which $\mathrm{X}$ is at pains to avoid. Cf. Isoc. 18.47-49.

${ }^{25}$ See 25.11, 22-23; cf. Antiphon's argument (II Tetr. A.4.9) that only the unfortunate poor support revolutions, whereas the rich want stability. J. Ober, Mass and Elite in Democratic Athens (Princeton 1989) 266, finds in the generalization at 8 and 10 an assurance that political loyalties need not be inherited, that aristocrats could support democracy. However, the Athenian people well knew of their aristocracy not only that it could support democracy for prestige and profit but that it in fact had done so for generations (Th. 8.48.6). Ober has overlooked the historical background against which the generalization is to be seen, the impoverishment of Athens (Lys. 28.2-3, 34.9).

${ }^{26}$ The amnesty offered immunity from prosecution; it did not exculpate (Arist. Ath. 39.6; And. 1.87, 94 offers a concrete instance). The speaker of Isoc. 18 admits that the Thirty had plenty of help from other Athenians (22-24), and Lysias states that members of the City faction for their own profit deliberately refrained from helping people marked down by the Thirty (12.49). After Thrasybulus's success at Phyle, the Thirty obliged the City faction to join with them in confiscating the goods and property of the citizens of Eleusis, whom they murdered after the mockery of a trial. They committed the same sort of atrocity on the Salaminians, again sharing the gains with the City faction to deepen their complicity (Xen. HG 2.4.8; Lys. 12.52, 13.44; Diod. 14.32.4). The amnesty addressed 
tiny or not, can hardly threaten him with destruction (5). (He names no penalty to which he would be subject if convicted.) The exaggeration surely refers to the awkward position of the City faction. At issue, then, is not personal accountability and self-interest but collective accountability and collective interest, which is the province of deliberative oratory. ${ }^{27}$ Again, when $\mathrm{X}$ refers to the possibility of future benefactions, it is as a spokesman for the strictly conditional loyalty of his entire faction

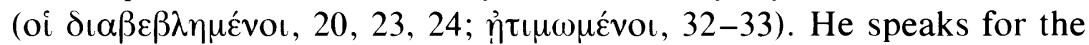
privileged group that felt its interests were best served by oligarchy in 404 , that came to have moral reservations about the Thirty, and that is now conditionally supportive of democracy. For example, in Lys. 12, "Against Eratosthenes," 'polis' and 'democracy' are as good as interchangeable terms; but this wealthy citizen discreetly but clearly distinguishes them $(25.11,25)$. Is democracy indispensable for all classes all of the time? In Or. 12 as spokesman for democracy, Lysias implies that it is, but $\mathrm{X}$ equivocates (10). The thing to dread from democratic restoration is not the isolated miscarriage of justice but a second, final round of civil war (18).

\section{HISTORICAL PARADEIGMATA}

To illustrate the key generalization at 8 and $10, \mathrm{X}$ reminds the court of two notorious demagögoi, Peisander and Phrynichus (9), who (he claims) began their political careers as democrats but ended up violent oligarchs.

the question of the legal vulnerability, not the moral responsibility, of the City faction (Arist. Ath. 40.1-2).

${ }^{27}$ Aristotle observes that deliberative oratory gives reduced scope for personal attacks on the adversary, or for remarks about oneself, or for attempts to stir feeling $(R h$. 3.17.10) but increased scope for generalizations such as the expedient ( $R h$. 1.3.5).

The speculative suggestion of D. Innes, "Gorgias, Antiphon and Sophistopolis," Argumentation 5 (1991) 221-31, that Or. 25, with editing, may have served as a model speech "suitable for adaptation by any suspected oligarch taken to trial" (228) can neither be proved nor disproved, because it takes us beyond the evidence. However, I question whether this sternly worded speech of its time, with more historical particulars and more factional nuances than Innes allows, can have been intended for such a purpose. Mantitheus in his scrutiny (16.10f.) and Evander in his presumed defense (26.3-5) both assume the role of ardent, exemplary citizen, while Philon's presumed defense rests on his unwillingness to take either side in the civil war (31.27). None, apparently, uses the approach taken by $\mathrm{X}$, which does not make it easier to regard Or. 25 as a plausible model speech. 
Peisander fled the vengeance of the resurgent democracy in 410 , condemned to death along with Antiphon and others for his part in the oligarchic revolution of the previous year. ${ }^{28}$ In 411 Peisander supported the return of Alcibiades in the assembly (Th. 8.48-49). He argued that

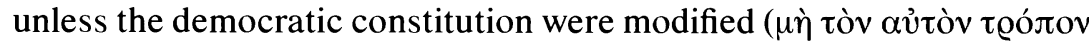
$\delta \eta \mu о \varkappa \varrho \alpha \tau o v \mu \varepsilon \dot{v o l \varsigma}, 8.53 .1)$, Alcibiades could not persuade the Persians to switch their funding from the Peloponnesians to the Athenians. Thucydides in no way suggests that Peisander nursed a grievance against the democracy in 411 that might have led him to work for an oligarchy. On the contrary, the people appear to have trusted him to the fullest extent: they would not otherwise have given him the task of probing the mutilation of the Herms in $415^{29}$ and would certainly not have made him head of an embassy to negotiate with Tissaphernes and Alcibiades as happened in 411 (Th. 8.54.2).

As a stratégos in 411, Phrynichus opposed the recall of Alcibiades (Th. 8.48, 50). Plotting to impose an oligarchy, he disclosed to the Spartan commander Astyochus details of negotiations between the Athenian conspirators, the satrap Tissaphernes, and Alcibiades, and offered to betray the Athenian fleet at Samos. By destroying democracy's power to resist Sparta and her allies, he would have made the installation of an oligarchy at Athens all but inevitable. Phrynichus saw in democracy an evil to be undermined by all available means, including internal subversion as planned and carried out by the oligarchic hetaireiai; in oligarchy he found a form of government that would advance his own interests and those of the other members of his class (Th. 8.68.3).

Both men wanted to reconcentrate in the hands of the kaloikagathoi the power and wealth which generations of democratic rule had caused increasingly to be at the disposal of an "unworthy" popular minority. ${ }^{30}$ The cases of Phrynichus and Peisander, then, fail to illustrate X's principle of constitutional preference. The record cannot be invoked to show that either man became an oligarch because the de-

${ }^{28}$ Th. 8.54.3-4, 67.3-68.1, 98.1; Lys. 12.66; Arist. Ath. 32.2; see R. Sealey, A History of the Greek City States: 700-338 B.C. (Berkeley 1976) 359.

${ }^{29}$ And. 1.36; Lys. 12.66 suggests that the people turned against him only when convinced that he was an ambitious oligarch masquerading as a democratic rhètór; see A. G. Woodhead, "Peisander," AJP 75 (1954) 131-46, esp. 141. From Lys. 7.4 it appears that Peisander was a landowner, and from Arist. Ath. 32.2 that he was well-born.

${ }^{30}$ Thucydides explicitly says that in 411 the most influential Athenians wanted an oligarchy which could win the war for them where democracy had failed (8.48.1). 
mocracy meant to punish him; and in the case of Peisander, evidence to the contrary is strong. ${ }^{31}$ On the other hand, the truth was more humiliating than $\mathrm{X}$ suggests: Phrynichus and Peisander, wolves in sheep's clothing, managed the subversion of democracy by constitutional means. Their names are a reminder that what has happened once may happen again, with radical democrats equally oblivious before the event. The overriding point is not that, in general, extremes meet, but that they are apt to do so in Athens where the pletthos is peculiarly, chronically gullible. ${ }^{32}$

\section{DEMOCRATIC POLITICAL PROSECUTIONS AND THE REVOLUTION OF $404 / 403$}

$X$ cites the democracy for unjust prosecution of certain citizens between the fall of the Four Hundred in 410 and the end of the Peloponnesian War (10-11). Some allegedly were put to death without trial, others had their property confiscated, forfeited civic rights, or were exiled (25-26). Allegedly, citizens are still being prosecuted for no other reason than their wealth $(3,30-31)$. These abuses are meant to show the two oligarchic regimes as consequences of a deep-seated disorder, the tendency of the people to heed sykophantai $(21,27)$.

Certainly, if we compare the sufferings of the people at the hands of the Thirty with the harassment to which a very few of the City faction were subjected by the restored democracy-Plato and Aristotle give impressive testimony to the democracy's faithful observance of the amnesty-we see how incommensurate are the two sets of $\dot{\alpha} \delta$ - $x \eta^{-}$ $\mu \alpha \tau \alpha .{ }^{33} \mathrm{~A}$ different standard is applied to the democrats from that ap-

${ }^{31}$ See A. Lintott, Violence, Civil Strife, and Revolution in the Classical City (London 1982) 151, 182, n. 37. On Phrynichus see also Ostwald (note 10 above) 348-50, esp. 349, n. 50; on Peisander, Ostwald 350.

${ }^{32}$ W. Voegelin, Die Diabole bei Lysias (Basel 1943) 139, misses the rhetorical point by not bringing into sharper focus the historical context; cf. Pl. Rep. 571c-573c. It is difficult to believe that in his account of the descent from oligarchic, to democratic, to tyrannical man Plato did not have Athenian radical democracy in mind. References to the gullibility of the Demos are collected by Ostwald (note 10 above) 225-29.

${ }_{33}$ According to Aristotle, fifteen hundred Athenian citizens died at the hands of the Thirty (Ath. 35.4). Isocrates puts the figure of those fleeing Athens for Piraeus in excess of five thousand (7.67). This does not keep $\mathrm{X}$ from saying that the men of Piraeus are to 
plied to the rich, whose natural concern was to see their fortunes left intact by the democracy. In scale, from a purely judicial point of view, the offenses perpetrated by one faction on the other are quite disproportionate, given the universally acknowledged brutality of the Thirty. However, there is no disproportion if the speaker's coldly rational, nonmoral point of view is appreciated for what it is, ${ }^{34}$ part of X's deliberative persona to be concerned strictly with results in the long term (sage

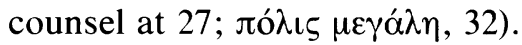

\section{COLLECTIVE PERSONA}

Several considerations lead us to distinguish X's persona as collective rather than individual. $X$ would have the public take account of a distinct political identity, not merely an individual with distinctive personal qualities. The rhetorical challenge of the speech is posed not to the individual, that he should conform to political expectations of his united fellow citizens (cf. Mantitheus in Lys. 16), but to the democratic majority, that they had better take thought of factional harmony, or else (30).

The following qualities distinguish X's collective persona:

(1) Concern with preserving fortunes. In general, X's discussion of political loyalties gives little importance to the civil war of $404 / 403$ as a theater in which events forced simple black-and-white moral choices on all Athenians; on the other hand, X strongly implies that by illegalities perpetrated beforehand the democracy in effect made war upon the best citizens, and so brought on its own demise. When comparing the relative merits of democracy and oligarchy, $X$ pledges loyalty to democracy as long as it is made worthwhile to citizens like himself (8). The absolute requirement to preserve wealth and property remains the

regard the men of the City en bloc as the former regarded themselves during their exile (20) - that is, as a group of citizens who receive unfair treatment with the result that the accords are undermined.

${ }^{34}$ Arist. Rh. 1.3.6. Cf. the speech of Diodotus, whose cold contribution to the Mytilenaean debate in Thucydides is introduced with the statement: "We are not judges in a court of law; we are a deliberative assembly, and the question is, How can Mytilene be most useful to Athens?" (3.44.4). The deliberation over the fate of Mytilene should be void of anger $(3.42 .1,44.4)$ and pity, however understandable these emotions (cf. 3.48.1 and Lys. 25.1). 
most reliable guarantee of that fundamental political unity among the City faction which $\mathrm{X}$ takes for granted and for which he feels no need to apologize (29). In fact, he assumes that no citizen is a wrongdoer merely by virtue of having put himself and his property under the protection of an oligarchy (18; cf. Ps.-Xen. 1.5, 14). On the other hand, he agrees to meet legitimate charges on his estate; and if the people advance him (13), they can trust him. ${ }^{35} \mathrm{He}$ recalls the restoration of democracy in 403 as the fruit of a gradual rapprochement of the City faction (21-22) with a few reasonable leaders of the Piraeus faction in the same social class with himself (28).

(2) Intellectual superiority (deinos phronein) vis-à-vis the Piraeus faction. $X$ does more than strike the customary pose of superiority relative to his accusers; he dares to be tolerant of the court itself, smugly excusing the notorious emotional excesses and delusions of the people. ${ }^{36}$ In reminding the court that Phrynichus and Peisander were demagogoi and that sykophantai would participate enthusiastically in oligarchic tyranny, given the chance, he accuses the majority of holding its loyal citizens in suspicion (33) ${ }^{37}$ while historically choosing its leaders among potential subversives (1,35; cf. Ps.-Xen. 2.20): in sum, he represents the democratic rank and file as knowing that they want democracy without knowing whom to trust with the leadership. ${ }^{38}$ Here (he seems to suggest) the upper classes have a contribution to make as physicians of the city's ills in time of defeat - this "speaker" would be less discreet in citing democratic abuses, more open and topical, if he saw no further role for himself in public life. The Thirty committed their crimes in the name of positive aristocratic virtues (Lys. 12.5), so $\mathrm{X}$

${ }^{35}$ Nothing in the careful language of Or. 25 suggests that $\mathrm{X}$ is currently an implacable enemy of democracy per se. He is prepared to live with it if not always to like it, to make the best of things (7). Cf. the arguments used by the defendant, Antipho. II Tetr. A.2.12, who also demands to be believed and cleared on the strength of his benefactions.

${ }^{36}$ Cf. 25.32-34, Ps.-Xen. Ath. Pol. 1.6-8, and what A. W. Gomme called "the sympathetic mockery of democracy" at Pl. Rep. 555b-558c. The magisterial form hegoumai is used eight times in the course of this brief speech, a record for Lysias $(2,5-7,11,17-$ $18,29)$. Stylistically, the speech makes frequent use of antithesis $(1,2,3,4,5,11,18,27,30)$.

${ }^{37}$ Contrast Lys. 26.1-4, a response from the democratic side to this sort of complaint.

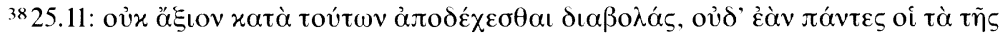

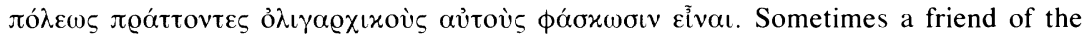
people must say unpopular things, recall the faltering intelligence of the pletthos to the exigencies of a situation. Cf. Th. 2.65.8-9 on Pericles; Ar. Eq. 1111-20; Xen. HG 2.4.41; Lys. 12.86 . 


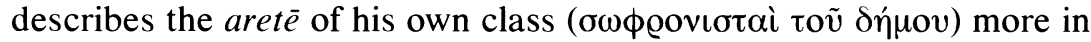
terms of what it is not-emotional, foolish, incompetent - than of what it is. But X identifies the greatest present evil as the democracy's mistreatment of citizens like himself, unfairly made into the scapegoats behind whom democratic poneroi take concealment (1). If not permitted to use their intelligence for the benefit of the community and for the enhancement of their own prestige, ${ }^{39}$ they (like Timon) want chiefly to be left alone. ${ }^{40}$

Failure to take into account the financially exhausted state of Attica and the delicate balance between the factions has contributed to wide disagreement among scholars over the persona assigned to $\mathrm{X}$. Or. 25 is that rara avis in the Orators, a polemical defense by an upholder of the City faction; but there are no good grounds for assuming it could not have been delivered in the tense political climate ca. 400. I conclude that X's arguments conform to a common aristocratic practice of condescending, even upbraiding, rhetoric in deliberative speeches (assumed, for example, in And. 2.27; Lys. 12.87, 26.5). There is nothing anomalous in such rhetoric, given the times. Poor judgment on the part of the people is rebuked with the reminder that it was the radical democrats who lost the war with Sparta and emptied the treasury. $\mathrm{X}$ bases his faction's claim to political prominence on its practical intellectual superiority over the democratic plethos.

$X$, then, sustains a generalized political persona and is not individually characterized. Rather, he represents a body of opinion, the City faction, whose coherence in Athenian politics persisted for years after the overthrow of the Thirty (they were, after all, the better-off citizens in an impoverished state). This much is clear from our sources: that the transition from a completely discredited oligarchy back to a widely discredited radical democracy was neither immediate nor smooth. ${ }^{41}$ In criticizing the intractable abuses of radical democracy, Lys. 25 gives concrete expression and point to Aristotle's observation (Ath. 40.1) that very many City men feared and distrusted the restored government to

${ }^{39} \mathrm{X}$ expresses his displeasure with fomenters of the oligarchic-democratic faction who favor a war policy, hold offices unconstitutionally, and have suddenly gone from poverty to riches (29-31).

${ }^{40}$ From 30 it is clear they want no part in any policy that might bring Athens into conflict with "the Greeks," that is, with Sparta and her allies. Cf. Hell. Oxy. 6-7 (1-2) on the place of this issue in the Athenian politics of 396/395; and I. A. F. Bruce, An Historical Commentary on the "Hellenica Oxyrhynchia" (Cambridge 1967) 51-54.

${ }^{41}$ Hignett (note 5 above) 294-97. 
the point that they had to be deprived of their option to emigrate by the strategem of Archinus. It also shows how a master speechwriter might credibly prepare a political defense which is all offense, smoothly threatening reprisal for future wrongs, leaving little doubt which faction was the better-endowed intellectually and materially, and which was the more important to Athens in its present misery. ${ }^{42}$ We may see this as an opportune rhetorical variation on the theme of moral superiority which had characterized the aristocratic propaganda of the Thirty Tyrants. ${ }^{43}$

UNIVERSITY OF TEXAS, Austin

T. M. MURPHY

${ }^{42}$ Lys. 21.13, 20; 30.22 .

${ }^{43}$ I am much indebted to Michael Gagarin for his comments and incisive criticisms as this article was being prepared, to the anonymous reviewer, and to Peter Green for his assistance with the larger project of which it is a part. 